RURAL SUSTAINABILITY RESEARCH 46(341), 2021

\author{
ISSN - 2256-0939 \\ (c) Latvia University of Life Sciences and Technologies, all rights reserved \\ http://www.Ilu.Iv/en/
}

\title{
Creating a Regulatory Framework for the ESG-investment in the Multimodal Transportation Development
}

\author{
Oleksandr Datsii ${ }^{1}$, Nataliia Levchenko ${ }^{2}$, Ganna Shyshkanova ${ }^{2}$, Oleg Platonov ${ }^{1}$, "George Abuselidze ${ }^{3}$ \\ ${ }^{1}$ Interregional Academy of Personnel Management, Ukraine \\ ${ }^{2}$ National University "Zaporizhzhia Polytechnic", Ukraine \\ ${ }^{3}$ Batumi Shota Rustaveli State University, Georgia
}

\begin{abstract}
The work states that the strategic guideline for building an effective competitive national transport system and prosperous using Ukrainian multimodal potential is the formation of a regulatory environment for scaling ESG-investment in the context of transformation to a "climate-neutral" economy. The absence of a unified methodology for (assessment) scoring ESG-direction of business as the basis for decision-making on ESG-investment is established in the world and national practice. For the first time, the author's model of scoring trends and regularities of business development is proposed in accordance with ESG-principles, in contrast to traditional trend dynamic models, which identifies and iteratively conceptualizes processes by the set of ESG-indicator components determined using the cocoupling-analysis toolkit (tools for assessing the cocoupling-effect). A classification of the cocoupling-effect has been developed and each of its types has been characterized. Possible options for ESG-effectiveness of business are identified, which conditionally correspond to the four zones of the ESG-investment decision-making matrix. A research on the expected cocoupling-effect of ESG-investment in the multimodal transportation development is carried out to validate the feasibility of implementation the author's scoring model for the ESG-direction of business and obtaining realistic results according to the data of the International Energy Agency and the State Statistics Service of Ukraine. An effective measures arsenal of creating the regulatory framework for ESG-investment in the multimodal transportation development is identified and a Roadmap is proposed for their high-quality implementation, which would ensure positive changes in Ukraine's position in the world ranking of countries by multimodal potential usage efficiency.
\end{abstract}

Keywords: ESG-investment; ESG-principles; effectiveness; business activity; cocoupling effect.

\section{Introduction}

Dynamic internationalization of international business and increasing transit traffic, fierce competition between countries for dominance in the world market of transport services, where competitive advantages are speed, safety and efficiency of transport, directly depend on the widespread use of multimodal transport (Kozak \& Fedoruk, 2020). Therefore, one of the strategic directions of the "National Transport Strategy of Ukraine until 2030" is to build an effective competitive national transport system and effective use of the multimodal potential of Ukraine.

It should be emphasized that Ukraine, at its geographical location, is at the crossroads of numerous international trade and trans-European corridors. Having direct access to the Black Sea, Ukraine's transport system is connected by land with such countries as Belarus, Poland, Slovakia, Hungary, Romania, Moldova and the Russian Federation, as well as by sea - with Turkey and Georgia (Ji, Abuselidze, \& Lymar, 2021; Abuselidze, 2021). However, the main dividends from Ukraine's favorable geographical location, which should remain in the country, are currently received by neighbors, who are actively developing their own transport and logistics capacity, creating conditions for increasing freight traffic and attracting additional investment in modernization of container services, thereby ensuring the competitiveness of their own transport systems in the global market of multimodal freight transport (Belashov, 2021). Ukraine, on the other hand, currently uses only $1 / 3$ of the available multimodal potential primarily for the following reasons:

- unpreparedness of the country's routes for large flows of goods due to low capacity of domestic connections (transshipment points, roads and railways) and lack of proper transport infrastructure, the development of which is hampered, primarily due to: lack of favorable environment 
for investment, imperfection of the Law "On Concession" and its inconsistency with the legislation on land use and land ownership, low level of protection of investors' interests and their property;

- The presence of a monopoly of both Ukrzaliznytsia and unloading (stevedoring) companies and providers of ancillary services in the seas, which leads to an increase in the cost of goods transportation;

- High regulatory costs and time lost according to World Bank's estimation;

- Quality of roads, insufficiency of rolling stock and locomotives;

- Ingrained corruption, etc.

According to experts (Van Duuren, Plantinga, \& Scholtens, 2016; Kotsantonis, Pinney, \& Serafeim, 2016; Eccles, Kastrapeli, \& Potter, 2017; Chris et al., 2017; AmelZadeh \& Serafeim, 2018; Grim \& Berkowitz, 2020; Kim \& $\mathrm{Li}, 2021$ ), the solution of the listed issues is possible subject to the activation of investment attraction. However, institutional investors still prefer ESG-investing (Environmental, Social, and Corporate Governance, (ESG)), as evidenced by its growing share in the volume of investments in the capital market. In particular, according to the Global Sustainable Investment Alliance (2018) in 2018, the worldwide management of more than 30 trillion US dollars was carried out precisely in accordance with the principles of ESG-investment (Pedro, 2020).

Interest in ESG investments has also grown among private investors. According to a survey of 1,000 active private investors from the United States conducted by Morgan Stanley in 2017, 75\% of respondents are interested in ESG investments because they intend to join the process of combating climate change and promote carbon neutrality, which is essential in the context of deepening of the climate crisis. At the same time, the greatest interest in ESGinvestment was formed by millennials - representatives of Generation Y (the generation born in the late XX century, that "grew up in prosperity"), who are convinced that ESGinvestment will help fight climate change and preserve the environment for present and future generations. Therefore, the issue of ESG-investing in the development of multimodal transportation, and hence the formation in Ukraine of a favorable regulatory environment for its scaling, is one of the urgent issues of today, which needs to be addressed immediately (Pedro, 2020).

Nevertheless, the attitude towards ESG-investment had changed drastically with the deepening of the climate crisis and a clear awareness of both society and business of climate threats. Therefore, the concept of ESG-investment slowly began to gain acceptance worldwide. And only with the signing of the Paris Climate Agreement (Verkhovna Rada of Ukraine, 2016) by the participating countries in 2015 did its scaling intensify. However, as it turned out, not every country is ready for its implementation, since ESGinvestment requires an appropriate regulatory framework. Ukraine is not an exception. Currently, there are only a few examples of investing in accordance with ESG-principles in Ukrainian practice and the main reason for this is the lack of an appropriate regulatory framework in the country.

Therefore, we begin our research on the creating the regulatory framework for ESG-investment with a brief excursion into the history of the origin of this phenomenon to convince that investing according to ESG-principles is not just a vogue or hype, but a long-term trend of responsible investing, to which humanity came with evolutionary development.

As already noted, the acronym ESG means the balance of Environmental $(E)$, Social $(S)$ and Governance $(G)$ components of sustainable development. Regarding the environmental component ( $E$-component), we would like to note that information on various aspects of the environment is contained even in the works of ancient scientists and philosophers (Gorban, 2016). Nevertheless, the idea of "aging of the earth" was presented and the foundations for the development of the idealistic concept of "the influence of mankind on the environment" were laid by German thinker I. Kant, who was considered to be founder of the doctrine of human interaction with the environment in his Natural Science Treatise (1755) for the first time.

A later interpretation of Kant's idea, namely the "infertility" of the mother earth, was reflected in the works of such famous scientists as E. Haeckel (who was a supporter of the theory of evolution and introduced the term "ecology" in 1869), and the Russian scientist K. Roulier. He started the stage of "autecological reductionism", which was marked by the discovery of a number of fundamental laws, such as Liebig's law of minimum, Shelford's law of tolerance, Lundegard-Poletayev's law, etc. (Gorban, 2016). However, that was not enough by the end of the 50 s of XX century. Therefore, the stage of autecological reductionism was replaced by the stage of synecological reductionism, in which the focus was on the analysis of the interaction of organisms (populations). Nevertheless, scientists' efforts to reduce the interaction of man and nature to the interaction of the population quickly ended and led to the establishment of a more progressive systemic approach to ecology, associated with the emergence and formation of a civilized society, namely the noosphere approach in the 1970 s.

It is no secret that its foundations were laid in the works of Ukrainian academician V. Vernadsky and American scientist A. Teneli in the 30 s of the twentieth century, but they became widespread only in the researches of their followers, in particular, in the works of Soviet academician V. Sukachev, the famous American ecologist Yu. Odum and other scientists. The significance of this approach is in promoting humanity's understanding of the global problem of modern civilization the threat of global ecological catastrophe, which is becoming increasingly crucial with rapid economic development in the second half of XX century and the beginning of the XXI century (Gorban, 2016).

Hence, the objectives of this work in order to ensure positive changes in Ukraine's position in the world ranking of countries on the effectiveness of using multimodal potential are a filigree study of the world experience in creating a regulatory framework for ESG investments in business during the transition to a "climate neutral" economy; development of a Roadmap and identification of effective measures for the qualitative implementation of responsible investments in the development of multimodal transportation in Ukrainian practice.

\section{Materials and Methods}

Studying the world experience, we are convinced that the world practice introduced a number of initiatives and regulations on standardization and certification of actions at each stage of transformation to ESG-investing - starting with the definition of ESG-principles, ESG-indicators system development, the forming information support and ESG- 
reporting, and ending with the ranking of ESG-results. In particular, the Principles of Responsible Investment, nonfinancial reporting standards were developed, including the GRI (Global Reporting Initiative) and the IIRC (International Integrated Reporting Council). Regarding the evaluation and scoring of projects, rating companies were established, in particular, RobecoSAM, which is one of the leaders in the market of rating according to the principles of ESG and development of sustainable development indices (Garlytska \& Sushchenko, 2017). However, a clear methodology for assessing the ESG-orientation of companies required for investment decisions has not been developed yet.

Currently, there are a number of proposals from scientists, consulting companies and rating companies on methods for calculating the ESG-indicator. In particular, the Balanced Scorecard method, the Dow Jones Sustainability Index (DJSI) method, the DSI 400 method, the Social Index (SI) method, the Corporate Philanthropy Index method, the Dow Jones Sustainability World Index (DJSWI) method and others.

Each of these methods proposed to use three indices: the environmental $E$-index to assess the company impact on the ecosystem, the social $S$-index to determine the company relationships with employees, customers and society (including incentives, working conditions, health and safety) and the governance $G$-index to evaluate the business management system, as well as the system of training and retraining of employees, the system of prevention of such illegal practices as corporate fraud and bribery (Pedro, 2020). However, the lack of a clear system of partial and summary indicators, as well as information support for their receipt complicates the implementation of these methods in practice.

In the course of the research, the following methods were used: economic and mathematical modeling based on correlation and regression analysis - in determining each of the components of the ESG-indicators; cocoupling analysis when assessing cocoupling-effect for ESG-investments; CSR / ESG meta-analysis - when scoring the ESG-indicator of multimodal transport; logical structuring - when developing a classification of cocoupling-effect for ESG investments; logical sequence - when developing the architectonics of bringing the integral indicators of each of the ESGcomponents into a single dimension (ESG-indicator).

\section{Results and Discussion}

The swift development led to an unprecedented scale of anthropogenic impact on the nature. This gives scientists a reason to state the aggravation of the global environmental crisis and finally consolidate the ideology of environmentalism, which requires a radical rethinking of the relationship between man and the environment, and, accordingly, changes in social and political life, decision-making on economic growth and capital investment.

Regarding the significance of the social component $(S$ component), we note that the idea of social responsibility dates back to the prehistoric period. There were some provisions on hiring workers, remuneration for work and etc. even in the collection of laws of the Mesopotamian king Eshnunna (XX century BCE) and in the code of laws of the Babylonian king Hammurabi (XVIII century BCE). At that time, the problem of social responsibility was considered through the prism of the ideas of building an "ideal state" and an effective social order. In particular, in this context, social responsibility issues are revealed in the works of Heraclitus, Plato and Aristotle (Berezyuk, 2017).

Issues of social responsibility do not lose their relevance among modern thinkers and scientists. Instead, the social responsibility acquired the status of the institute only with the publication of G. Bowen (2013) in the scientific work "Corporate Social Responsibility" (CSR) in 1953. G. Bowen proposed the concept of CSR and proved its necessity. However, it became widespread only in the late 80 s. One of its most significant shortcomings was the business's solution of social and environmental issues through charity that was indirectly, without linking them with their production processes and production volumes.

The Carroll Pyramid was important in the CSR concept development. It was created in the early 1990s. The original form of the pyramid had four components: economic responsibility, legal, ethical and philanthropic. However, the business priorities were changed with time and the Carroll Pyramid was modified by F. Wieser into a CSR pyramid for developed countries. With the development of international relations, British scientists also slightly modified the pyramid, introducing the concept of "glocal social responsibility" of business (Berezyuk, 2017).

A new version of CSR so-called Creating Shared Value (CSV) was the most noteworthy among the latest modifications of the social responsibility concept. M. Porter and M. Kramer proposed it in 2011 (Porter \& Kramer, 2011). This version, unlike the previous ones, provided a demonstration of the contribution of companies in addressing social and environmental issues. According to its authors, it was an attempt to move from agreements to real actions, which were to provide a common value as a result of appropriate efforts to improve working conditions, health and safety (Garlytska \& Sushchenko, 2017).

Instead, both the CSR and CSV concepts did not contribute to capital inflows to address these issues. Only the adoption of the Paris Climate Agreement based on the analysis of the shortcomings of previous concepts proved the need to include in the responsible investment $S$-component. $S$-component is able to combine not only the interests of all participants, but also to transform from a voluntary approach to climate change to new business models, new approaches to investing and lending (Garlytska \& Sushchenko, 2017).

Regarding the Governance component ( $G$-component), we note that the concept of "corporate governance" came into use with the publication of article "Management Perspectives" by I'ral (1983). Instead, the relevance of corporate governance research was observed only when the Organization for Economic Cooperation and Development (OECD) developed the Guide to Corporate Governance in 1998. However, corporate governance is still a topical issue, despite years of research. The reason for this is the constant transformational changes in economy, the deepening of globalization and the climate crisis, etc. Therefore, corporations strive to ensure an effective management decisionmaking process, balance the interests of stakeholders, integrity and openness of business (Khasanov, 2015).

Consequently, ESG-investment is a form of responsible business investment with a high level of corporate governance, which operates on the principles of environmental and social responsibility to the present and future generations for a safe environment and their well-being.

However, despite its advantages over other types of 
investment, ESG-investment has been perceived differently by businesses, as on the one hand it only indirectly affects the solution of climate problems, and on the other hand requires additional costs, which leads to partial loss of business profitability.

Supporting the above proposals for the assessment of ESG-indicator of business orientation, we consider it more appropriate to use the method of integrated evaluation. Its essence is the step-by-step calculation of partial, generalized and integral indicators of the each ESG-components, which should become the fundamental basis for assessing the achievement of ESG-goals by a business and correspondent determination of the ESG-indicator value.

Schematic representation of the architecture of bringing the integrated indicators of each of the components of the ESG into a single dimension (ESG-indicator) is shown in Figure 1 demonstrating the algorithm sequence.
First of all, the chain indices (namely $T_{E}, T_{S t}$ and $T_{G t}$ ) and growth rates (namely $K_{E t}, K_{S t}$, and $K_{G t}$ ), as well as the chain indices and growth rates of the ESG-factor (in particular, GDP), are determined basing on the partial indicators of each of the ESG-components. If the value of each $i$-indicator in the $t$-period exceeds 0 , it indicates a tendency to increase relative to the baseline indicator in the $(t-1)$ period. Conversely, if the value of any $i$-index in the $t$-period is lower than or equal to 0 , it indicates a tendency to decrease relative to the baseline indicator in the $(t-1)$ period.

The cocoupling approach makes possible to understand whether the investment is appropriate in terms of compliance with ESG-principles, in contrast to the decoupling approach. Further, the CocouplingIndex is determined for each of the ESG components guiding the cocoupling approach. CocouplingIndex is shortly designated as CCI in Figure 1.

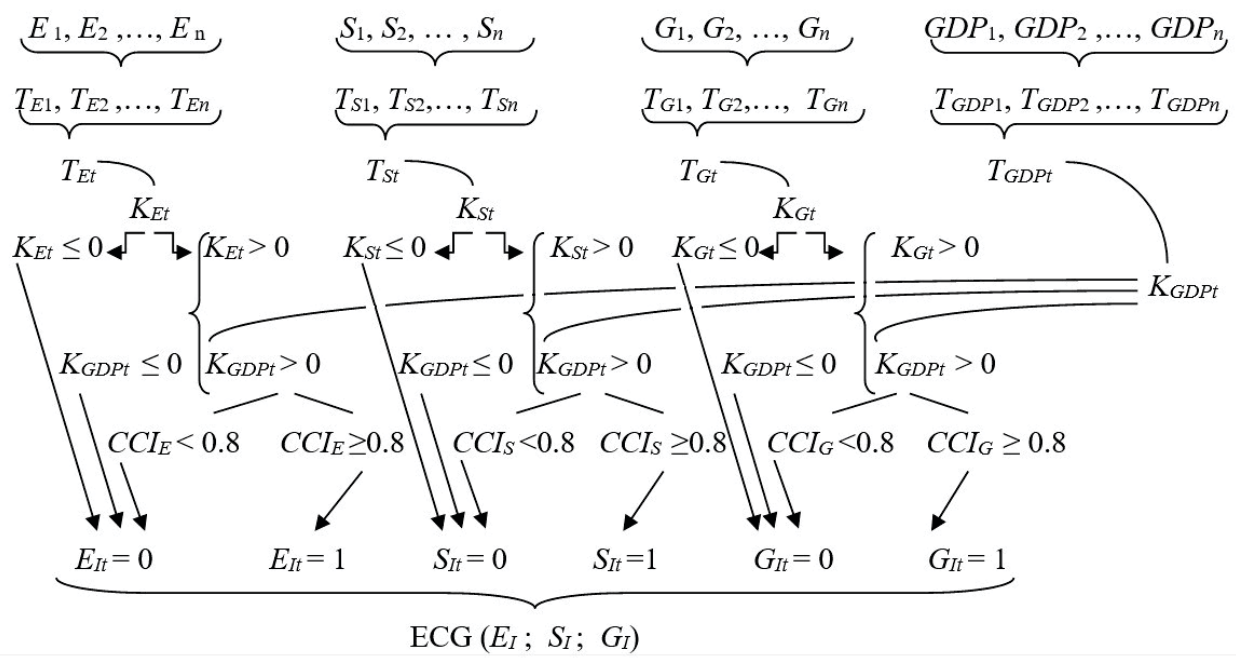

Figure 1. Schematic representation of the architectonics of bringing the integrated performance of each of the components of the ESG into a single dimension (ESG-indicator).

It is CocouplingIndex that reflects how much a particular component of ESG will change in a given period of time in the event of a change in economic growth by $1 \%$, and thus provides an opportunity to establish the relationship between ESG factors and ESG business performance, i.e. to establish a cocoupling effect:

$$
\text { CocouplingIndex }=\frac{\left(\frac{E S G_{-} I}{D F}\right)_{\text {ending }}}{\left(\frac{E S G_{-} I}{D F}\right)_{\text {beginning }}}=\frac{K_{E S G_{-} \text {Iending }}}{K_{\text {DFbeginning }}}
$$

where $E S G I_{-} \quad$ is an indicator of ESG components growth, physical or monetary units;

$D F$ is driving force, an indicator of economic growth GDP), monetary units;

$K_{E S G-I}, K_{D F}$ are growth rates of relevant indicators.

Taking into account the possible variants of the cocoupling effect, we consider it expedient to classify its types by analogy with the P. Tapio's classification of the decoupling effect types (Tapio, 2005) and distinguish coupling, cocoupling and divergent-cocoupling (Figure 2). 


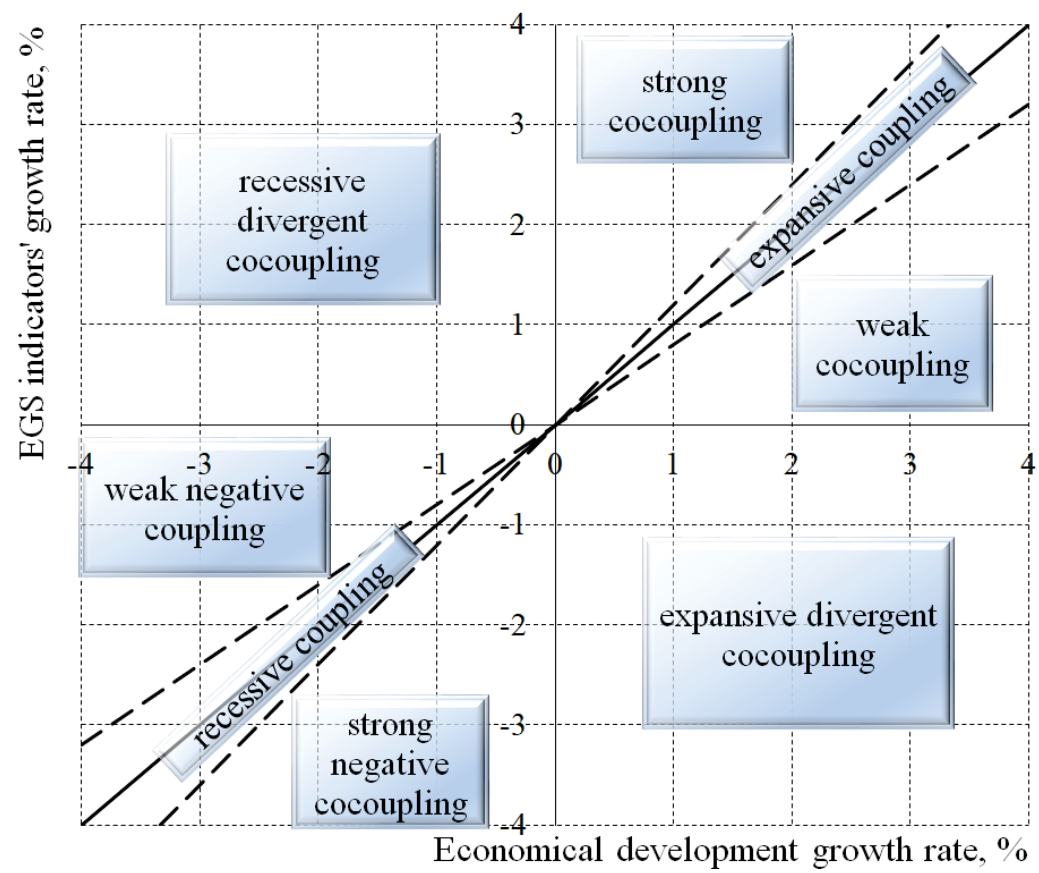

Figure 2. Classification of types of cocoupling effect.

In particular, coupling effect is observed when the economic growth rate approaches the growth rate of ESG components. It can be:

expansive coupling-effect - if the growth rate of economic growth and the growth rate of $E S G$ components tend to increase;

recessive coupling-effect - if the growth rate of economic growth and the growth rate of ESG components tend to decrease.

Instead, in both cases, the coupling-effect is considered to be present only if $0.8<$ CocouplingIndex $<1.2$.

Cocoupling-effect is observed under the condition of identical direction of changes of both economic growth indicators and $E S G$ components (i.e. under condition of their simultaneous growth or simultaneous decline), but at different rapidity (speed) of their rates. Therefore, we consider it expedient to distinguish according to the relative rapidity (speed) rate of change:

weak cocoupling-effect is prosesent under the condition of simultaneous increasing of both economic growth indicators and ESG components, when the growth rate of the former exceeds the latter ones, i.e. provided that the CocouplingIndex is in the range $0<$ CocouplingIndex $<0.8$;

strong cocoupling-effect is present in the case of simultaneous increasing of both economic growth and ESG components, but when the growth rate of the latter exceeds the growth rate of economic growth, i.e. when CocouplingIndex $>1.2$

weak negative cocoupling-effect is present in the case of a simultaneous decline in both economic growth and ESG components, but when the growth rate of decline in economic growth exceeds the rate of decline of the latter, i.e. when $0<$ CocouplingIndex $<0.8$;

strong negative cocoupling-effect is present under the condition of simultaneous decline in both economic growth indicators and $E S G$ components, when the decline rate of the latter exceeds the decline rate of economic growth indicators, i.e. when CocouplingIndex $>1.2$.

Divergent-cocoupling is observed under the opposite direction of changes in economic growth indicators and $E S G$ components, i.e. when CocouplingIndex $<0$. We consider it expedient to distinguish:

expansive divergent-cocoupling effect is provided that the growth rate of economic growth increases while the growth rate of ESG components decreases;

recessive divergent-cocoupling effect, is provided that the growth rate of economic growth decreases while the growth rate of $E S G$ components increases.

After CocouplingIndex determination for each of the ESG components, the ESG indicator should be proceeded to the calculation. The ESG component should be equated to one if the corresponding CocouplingIndex $\geq 0.8$. Conversely, the ESG component should be equated to zero if the corresponding CocouplingIndex $<0.8$. Therefore, if the value of all ESG components is equal to their sufficient value (CocouplingIndex $\geq 0.8$ ), the ESG indicator takes the following form, i.e. ESG effectiveness of the business is excellent and ESG-investment is appropriate:

$$
\mathrm{ESG}=f(1 ; 1 ; 1)
$$

If the value of all ESG components is below a sufficient level (CocouplingIndex $<0.8$ ), the ESG indicator takes the following form:

$$
\mathrm{ESG}=f(0 ; 0 ; 0)
$$

Consequently, the ESG effectiveness of the business is unsatisfactory. Therefore, the decision to invest in ESG should be negative.

Considering the construction of the ESG indicator by the triple result method, eight options for ESG effectiveness of the business are possible, which conditionally correspond to the four zones for making an ESG-investment decision (Figure 3).

Thus, since there are several options for situations with the deviation of certain components of the ESG indicator, we consider it appropriate to make the final decision on ESGinvestment over most of the values of its components. Thus, if the ESG is characterized as $(1 ; 0 ; 1)$, the final decision on the implementation of ESG-investment should be positive, and vice versa, if the ESG is characterized $(0 ; 0 ; 1)$, the final decision should be a refusal to invest. 


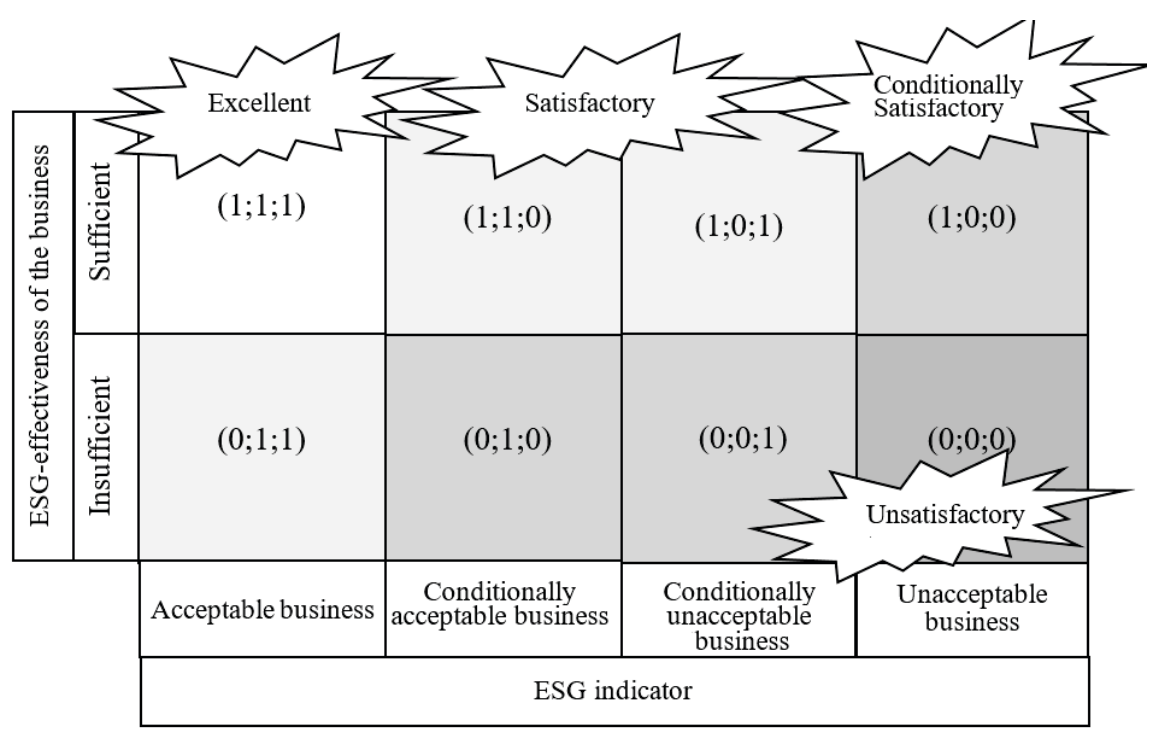

Figure 3. Matrix of ESG effectiveness zones according to the ESG indicator.

Whereas Ukraine has set as its goal the development of multimodal transportation and has identified the Second Nationally Determined Contribution of Ukraine to the Paris Climate Agreement on the reduction of Greenhouse Gas Emissions, we are going to carry out studies of the expected cocoupling effect of ESG investment in this particular industry in order to make sure that it is appropriate to put into practice the proposed assessment methodology and obtain realistic results for scoring the ESG orientation of business. The statistical data are used from the International Energy Agency (IEA), the National Cadastre of Anthropogenic Emissions from Sources and Absorption by Sinks of Greenhouse Gas in Ukraine for 1990-2017 (Ministry of energy and environment protection of Ukraine, 2019; Senyk, 2016; Senyk, 2018; Senyk, 2020; Werner, 2020; National accounts of Ukraine, 2020).

Let us calculate the CocouplingIndex to determine the type of cocoupling effect and possibilities to attract ESG investments in the multimodal transport development for each of the components of the $E S G$, using formula (1). The following notations should be introduced:

is Gross domestic product in transport of Ukraine at constant prices, UAH million;

is a carbon footprint $\left(\mathrm{CO}_{2}\right.$ emissions $)$ of transport, $\mathrm{Mt}$; $\overline{G D} P$ is an average monthly salary of full-time employees of transport, UAH;

$S_{l}$ are allowances and surcharges to tariff rates and salaries, UAH million;

$S_{1}$ are systematic bonuses and surcharges to remuneration, UAH million;

$S_{1}$ are incentive and compensation payments, UAH million;

$S_{I}$ is payment for unworked time, UAH million;

$G_{1}$ is training of transport workers who learned new professions, thousand people;

$G_{l}$ is advanced training for professional development of transport workers, thousand people.

In particular, CocouplingIndex $(E, G D P)$, i.e. the $E$ -

component of the $E S G$ indicator is determined by the

CocouplingIndex $(E, G D P)=\frac{K_{E t}}{K_{G D P t}}$ where $t$ is year;

$K_{E t}$ are chain reduction rates of $\mathrm{CO}_{2}$ emissions from transport, which are selected as an E-component in the ESG (reduction corresponds to negative growth rate);

$K_{\text {GDP } t}$ are chain GDP growth rates in transport.

Therefore, $K_{E t}$ is calculated as:

$$
K_{E t}=-\left(T_{E t}-100\right)^{, \%}
$$

$K_{G D P t}$ is calculated similarly to (5), but with a positive sign, according to the following formula:

$$
K_{G D P t}=T_{G D P t}-100, \%
$$

where $T_{E t}$ and $T_{G D P t}$ are indices of the respective indicator

$$
T_{t}=\frac{y_{t}}{y_{t-1}} \cdot 100 \%
$$

Where $Y_{t}$ is the value of the relevant indicator in the year in consideration;

$Y_{t-1}$ is the value of the relevant indicator in the previous year. To calculate the CocouplingIndex $(E, G D P)$, i.e. the $E$ component of the $E S G$ indicator, we use the data of IEA on $\mathrm{CO}_{2}$ emissions by sectors of the Ukrainian economy during 2010-2019, given in Table 1 (Data \& Statistics, 2021). 


\section{$\mathrm{Co}_{2}$ emissions dynamics by sectors of Ukrainian economy during 2010-2019}

\begin{tabular}{|l|c|c|c|c|c|c|c|c|c|c|}
\hline \multicolumn{1}{|c|}{ Indicator, Mt } & $\begin{array}{c}201 \\
0\end{array}$ & 2011 & 2012 & 2013 & 2014 & 2015 & 2016 & 2017 & 2018 & $\begin{array}{c}201 \\
9\end{array}$ \\
\hline Energetics & 123 & 131 & 134 & 130 & 111 & 90 & 101 & 83 & 88 & 91 \\
\hline Other energy sectors & 7 & 5 & 6 & 5 & 5 & 4 & 4 & 3 & 3 & 3 \\
\hline Industry & 61 & 65 & 61 & 57 & 56 & 42 & 38 & 31 & 36 & 35 \\
\hline Transport & 34 & 34 & 31 & 31 & 27 & 23 & 24 & 25 & 25 & 24 \\
\hline $\begin{array}{l}\text { Housing and communal } \\
\text { services }\end{array}$ & 35 & 36 & 35 & 35 & 29 & 23 & 23 & 22 & 24 & 23 \\
\hline $\begin{array}{l}\text { Commercial and public } \\
\text { services }\end{array}$ & 2 & 2 & 2 & 2 & 3 & 1 & 2 & 2 & 3 & 2 \\
\hline Agriculture & 4 & 5 & 5 & 5 & 4 & 4 & 5 & 4 & 4 & 4 \\
\hline
\end{tabular}

In particular, greenhouse gas emissions by the transport sector of Ukraine account for more than $1 / 6$ of the total emissions in 2019. Therefore, primary, there is the question of the ability and focus of the multimodal transportation business to reduce carbon emissions and the possibility to attract ESG-investment.

When calculating the CocouplingIndex $(S, G D P)$, i.e. the $S$ component of the ESG indicator, an integrated approach is proposed, defining the integrated indices of $S$-factors as the geometric mean of their indices. The geometric mean of several positive real numbers is a number that can replace each of these numbers so that their product does not change. Therefore, using the $S$-factors indices obtained by formula (7), an integrated indicator of the $S$-component indices of the ESG indicator is computed according to the following formula:

$$
T_{S t}=\sqrt[5]{T_{S 1 t} \cdot T_{S 2 t} \cdot T_{S 3 t} \cdot T_{S 4 t} \cdot T_{S 5 t}}, \%
$$

The integrated $S$-component growth rate of the ESG indicator is calculated using formulae (6), (8) as follows:

$$
K_{S t}=T_{S t}-100, \%
$$

Hence, CocouplingIndex $(S, G D P)$ is found similarly to (4)

CocouplingIndex $(S, G D P)=\frac{K_{S t}}{K_{G D P t}}$,

The data presented in table 2 are used to calculate the CocouplingIndex $(S, G D P)$.

\section{Dynamics of $S$-component partial indicators of the ESG indicator in the transport sector of Ukraine during 2010-2019, UAH million}

\begin{tabular}{|l|l|l|l|l|l|l|l|l|l|l|}
\hline \multirow{2}{*}{ Indicator } & \multicolumn{9}{|c|}{ Year } \\
\cline { 2 - 12 } & 2010 & 2011 & 2012 & 2013 & 2014 & 2015 & 2016 & 2017 & 2018 & 2019 \\
\hline wage fund & $\begin{array}{l}2452 \\
3\end{array}$ & 28131 & 31885 & 1162 & 12994 & $\begin{array}{l}14581 . \\
3\end{array}$ & $\begin{array}{l}19565 . \\
3\end{array}$ & 26706 & 31762 & 37085 \\
\hline $\begin{array}{l}\text { allowances and } \\
\text { surcharges to tariff } \\
\text { rates and salaries }\end{array}$ & $\begin{array}{l}3089 . \\
9\end{array}$ & 3488.2 & 3730.5 & $\begin{array}{l}1216 . \\
7\end{array}$ & 1533.3 & 1093.6 & 1682.6 & $\begin{array}{l}2991 . \\
1\end{array}$ & $\begin{array}{l}3906 . \\
7\end{array}$ & 4338.9 \\
\hline $\begin{array}{l}\text { systematic bonuses } \\
\text { and surcharges to } \\
\text { remuneration }\end{array}$ & $\begin{array}{l}2893 . \\
7\end{array}$ & 3488.2 & 3985.6 & $\begin{array}{l}1093 . \\
9\end{array}$ & 1195.4 & 1472.7 & 2289.1 & $\begin{array}{l}3204 . \\
7\end{array}$ & $\begin{array}{l}4319 . \\
6\end{array}$ & 5229.0 \\
\hline
\end{tabular}




\begin{tabular}{|l|l|l|l|l|l|l|l|l|l|l|}
\hline $\begin{array}{l}\text { incentive and } \\
\text { compensation } \\
\text { payments }\end{array}$ & $\begin{array}{l}1667 . \\
6\end{array}$ & 1997.3 & 2423.3 & 837.2 & 1091.5 & 1093.6 & 1682.6 & $\begin{array}{l}2590 . \\
5\end{array}$ & $\begin{array}{l}3017 . \\
4\end{array}$ & 3003.9 \\
\hline $\begin{array}{l}\text { payment for } \\
\text { unworked time }\end{array}$ & $\begin{array}{l}2305 . \\
2\end{array}$ & 2588.1 & 2582.7 & 971.1 & 1195.4 & 1399.8 & 1780.4 & $\begin{array}{l}2350 . \\
1\end{array}$ & $\begin{array}{l}2795 . \\
1\end{array}$ & 3523.1 \\
\hline $\begin{array}{l}\text { average monthly } \\
\text { salary of full-time } \\
\text { employees of } \\
\text { transport }\end{array}$ & 3683. & 4435.5 & 4821.5 & 5186. & 5724.5 & 8092.8 & 10684. & $\begin{array}{l}13387 \\
.2\end{array}$ & $\begin{array}{l}16291 \\
.2\end{array}$ & $\begin{array}{l}15691 . \\
5\end{array}$ \\
\hline
\end{tabular}

Analogically for determining the CocouplingIndex $t_{t}(G$, $G D P$ ), the integrated approach is used to calculate the integrated $G$-component growth rate of the $E S G$ indicator as the geometric mean of their indices, similarly to formulae (8), (9):

$$
K_{\mathrm{G} t}=T_{G t}-100^{,(\%)}
$$

$$
T_{G t}={\sqrt{T_{G 1 t} \cdot T_{G 2 t}}}^{,(\%)}
$$

Thus, CocouplingIndex $(G, G D P)$ is found similarly to formulae (4), (10):

$$
\text { CocouplingIndex } t_{t}(G, G D P)=\frac{K_{G t}}{K_{G D P t}}
$$

The data given in Table 3 are used to calculate the CocouplingIndext (G, GDP).

\section{Dynamics of $G$-component partial indicators of the ESG indicator in the transport sector of Ukraine during 2010-2019}

\begin{tabular}{|l|c|c|c|c|c|c|c|c|c|c|}
\hline \multicolumn{1}{|c|}{ Indicator, (thousand people) } & $\begin{array}{c}201 \\
0\end{array}$ & 2011 & 2012 & $\begin{array}{c}201 \\
3\end{array}$ & $\begin{array}{c}201 \\
4\end{array}$ & $\begin{array}{c}201 \\
5\end{array}$ & $\begin{array}{c}201 \\
6\end{array}$ & 2017 & 2018 & 2019 \\
\hline $\begin{array}{l}\text { Training and professional } \\
\text { development of employees }\end{array}$ & 91.6 & 110.3 & 106.7 & 26.8 & 30.2 & 32.1 & 32.5 & 32.6 & 33.3 & 33.6 \\
\hline \multicolumn{1}{|l|}{ including } \\
\hline $\begin{array}{l}\text { training of transport workers who } \\
\text { learned new professions }\end{array}$ & 19.1 & 25.2 & 22.9 & 5.5 & 4.8 & 4.9 & 5.1 & 5.3 & 5.4 & 5.5 \\
\hline $\begin{array}{l}\text { advanced training for professional } \\
\text { development of transport workers }\end{array}$ & 72.5 & 85.1 & 83.8 & 21.3 & 25.4 & 27.2 & 27.4 & 27.3 & $\begin{array}{c}27 . \\
9\end{array}$ & 28.1 \\
\hline
\end{tabular}

The results of CocouplingIndex calculations for each of the components of the ESG-indicator are given in Table 4.

\section{CocouplingIndex for each of the ESG-indicator components of multimodal transportation business during 2010-2019}

\begin{tabular}{|l|c|c|c|}
\hline \multirow{2}{*}{ Year } & \multicolumn{3}{|c|}{ CocouplingIndex } \\
\cline { 2 - 4 } & E-component & S- component & G-component \\
\hline 2011 & 0 & 0.7062 & 1.0084 \\
\hline 2012 & 2.7085 & 3.0601 & -1.6587 \\
\hline 2013 & 0 & -21.9651 & -28.3341 \\
\hline 2014 & -2.4480 & -3.7054 & -0.3824 \\
\hline 2015 & 3.1719 & 1.6748 & 0.9752 \\
\hline 2016 & -0.1048 & 1.0597 & 0.0577 \\
\hline
\end{tabular}




\begin{tabular}{|l|c|c|c|}
\hline 2017 & -0.2397 & 2.5703 & 1.5464 \\
\hline 2018 & 0 & 1.3299 & 0.8854 \\
\hline 2019 & 0.1803 & 0.4598 & 0.4177 \\
\hline
\end{tabular}

Data from Table 4 convincingly show that environmental, social and corporate orientation of capital investing in the multimodal transportation development is currently accompanied by a weak cocoupling-effect, which can be seen in Figure $4(a-c)$ for each of the ESG components.

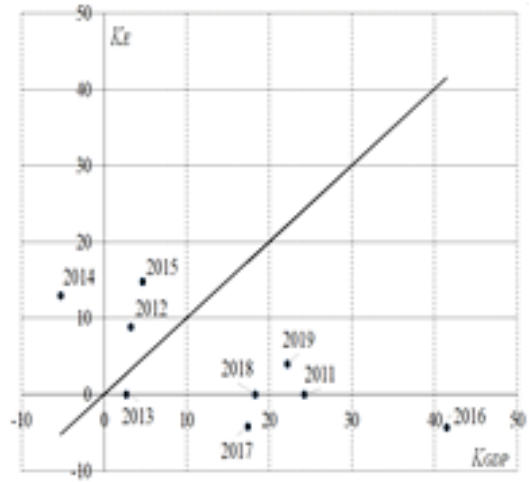

a)

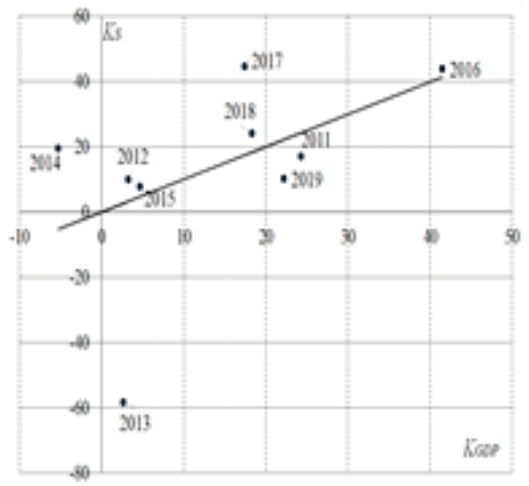

b)

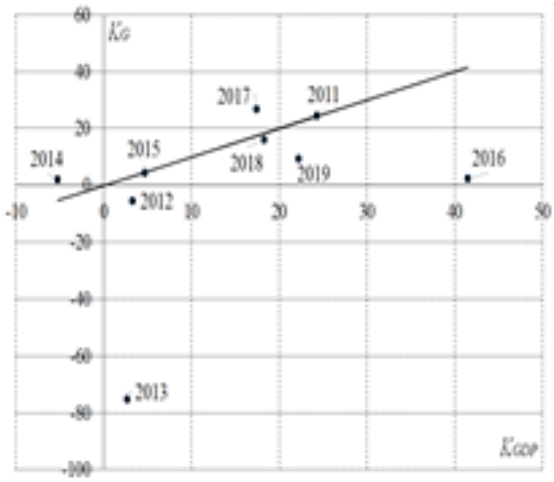

c)

Figure 4. Cocoupling effect on the multimodal transport development during 2010-2019:

a) E-component; b) S- component; c) G- component.

Thus, we conclude that Nationally Determined Contribution of Ukraine according to the Paris Agreement-2 (NDC2) (Ministry of energy and environment protection of Ukraine, 2019) is essential reduction of greenhouse gas emissions in the economy as a whole and, in particular, in the field of multimodal transportation and its implementation requires additional investment. Institutional investors are presently ready to invest in the multimodal transport development in Ukraine, since Ukraine is an important land bridge between Europe and Asia, as well as between the Baltic and Black Seas, but only in compliance with ESG principles.
The multimodal transport business is currently in the initial stages of transformation to the low-carbon economy, and therefore, the integrated indicators for each of the ESG components are quite low, while most components tend to grow. Therefore, the domestic business of multimodal transportation is worth ESG investment, subject to annual reporting on compliance with ESG principles.

Mathematical forecast techniques and data presented in Table 1 and Table 5 are used to calculate the need for ESG investment required to reduce the carbon footprint of multimodal transportation.

Table 5

\section{Dynamics of $E S G$-factors during 2010-2019}

\begin{tabular}{|l|c|c|c|}
\hline Year & $\begin{array}{c}\text { Capital investments in } \\
\text { transport, UAH million }\end{array}$ & $\begin{array}{c}\text { Annual salary fund per } \\
\text { full-time employee on } \\
\text { average, UAH million }\end{array}$ & $\begin{array}{c}\text { The ratio of the number of employees } \\
\text { who have been trained and retrained to the } \\
\text { average number of full-time employees }\end{array}$ \\
\hline 2010 & 1714.677 & 0.034 & 0.126 \\
\hline 2011 & 1794.320 & 0.039 & 0.153 \\
\hline 2012 & 2229.278 & 0.043 & 0.145 \\
\hline 2013 & 2257.350 & 0.041 & 0.098 \\
\hline 2014 & 1686.948 & 0.045 & 0.105 \\
\hline 2015 & 2789.194 & 0.055 & 0.120 \\
\hline 2016 & 2668.813 & 0.069 & 0.115 \\
\hline 2017 & 2992.111 & 0.095 & 0.140 \\
\hline 2018 & 3720.598 & 0.120 & 0.165 \\
\hline
\end{tabular}




\begin{tabular}{|l|l|l|l|}
\hline 2019 & 4096.834 & 0.141 & 0.185 \\
\hline
\end{tabular}

Source:Senyk,2016;Senyk,2018;Senyk,2020;Petrenko,2016;Petrenko,2018Letusfindnextmultifactorialnonlinear dependences

$$
\begin{aligned}
E & =f(I ; G D P) \\
S & =f(I ; G D P) \\
C & =f(I ; G D P)
\end{aligned}
$$

The coefficients of multifactor nonlinear regressions (14)(16) are found by the generalized least squares method (Greene, 2018) after the initial linearization with the help of substitutions. We choose the form of nonlinear models with the help of the developed software algorithm by the directed enumeration method (Savchenko, 2012) of power and logarithmic dependences (Shyshkanova, 2018; Tian et al., 2018). The criterion for the best fit of the model to reality is the least sum of squares of residuals in comparable models.

Therefore, the dependence (14) is proposed in the next form:

$$
E=426.46-239.73 \cdot \sqrt[4]{\ln I}+0.16 \cdot 10^{-5} \cdot G D P
$$

A negative sign of the numerical coefficient before $I$ in formula (17) means that the growth of capital investment contributes to the reduction of $\mathrm{CO}_{2}$ emissions and the preservation of the environment. On the contrary, the growth of GDP leads to increase in greenhouse gas emissions, which is explained by an increase in traffic. The corresponding surface to the regression (17) is constructed in Figure $5 \mathrm{a}$.

The following regression (15) is proposed in the following form of an economic and mathematical model:

$$
S=-0.11+0.03 \cdot \sqrt[5]{I}+\left(1.32 \cdot 10^{-6} \cdot G D P\right)^{2}
$$

The established dependence (18) of the S-component on capital investments in the development of multimodal transportation and GDP of transport shows that with an increase in variables, the $S$-component function also tends to increase, that is, to an increase in corporate social responsibility and the development of the social sphere. On the other hand, GDP should be recognized as a more influential factor in the rate of change of, as evidenced by the dependence of the second degree. The shape of the dependence of the ESG indicator $S$-component (18) is performed in Figure $5 \mathrm{~b}$.

Regarding regression (16), we consider it reasonable to present it in the next form:

$$
G=0.12+\left(3.40 \cdot 10^{-5} \cdot I\right)^{3}+\left(1.70 \cdot 10^{-6} \cdot G D P\right)^{2}
$$

All numerical coefficients are positive in (19), so the growth of investment and GDP leads to the growth of the ESG indicator $G$-component. The influence of both factors is almost the same in nature, i.e. corresponds to the dependence of the third degree. The surface, which is constructed according to (19) in Figure $5 \mathrm{c}$, is more convex downwards than in Figure 5 a.

Fisher's test, $F>F_{c r}$ (Table 6) shows with a reliability of $90 \%$ (the level of significance is $\alpha=0.1$ that appropriate $R^{2}$ can be considered statistically significant; the proposed mathematical models (17)-(19) are enough adequate to the statistical data and on the basis of the adopted simultaneous regressions system is worthy of application in decisionmaking on ESG-investing in the multimodal transport development.

Table 6

Coefficients for the analysis of the adequacy of the proposed mathematical models

\begin{tabular}{|c|c|c|c|}
\hline Number of regression & $R^{2}$ & $F$ & $F_{c r}(?=0,1)$ \\
\hline 17 & 0.57 & 4.65 & \multirow{2}{*}{3.26} \\
\hline 18 & 0.98 & 150.59 & $\left(k_{1}=2, k_{2}=7\right)$ \\
\hline 19 & 0.59 & 4.96 & \\
\hline
\end{tabular}

Regression surfaces (17) - (19) are shown in Figure 5, respectively.

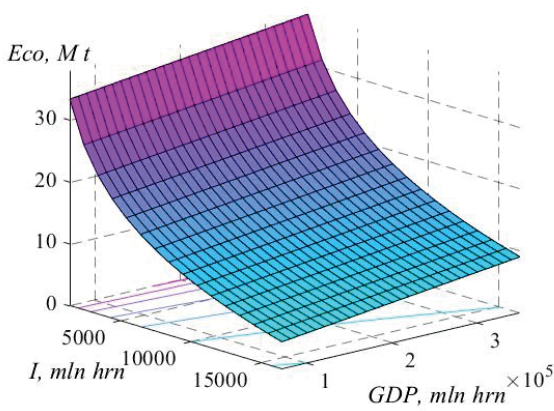

a)

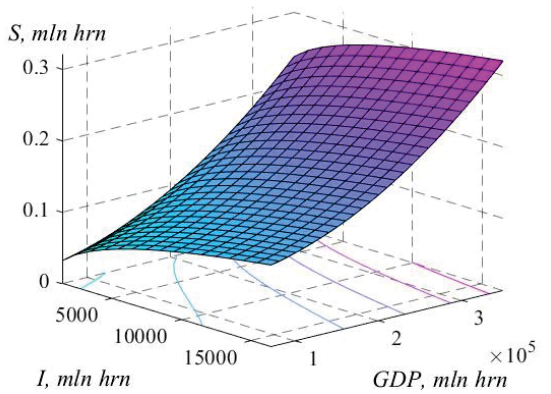

b)

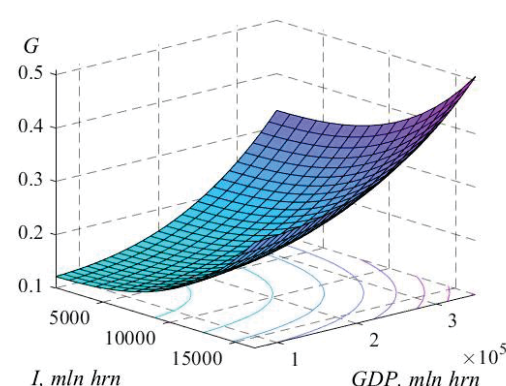

c)

Figure 5. Regression surfaces: a) E-component; b) S- component; c) G- component. 
$\mathrm{CO}_{2}$ emissions from transport should be $E=10.45 \mathrm{Mt}$ in 2030 to achieve climate neutrality in the long term perspective according to (Support to the government of Ukraine on updating its nationally determined contribution C40502/8492/47661) and GDP should be provided at the level of 326839.8 million UAH in 2030 basing on the average GDP growth rate of 3\% per year. Therefore, using (17), we calculate the amount of capital investment in the development of multimodal transportation and find out that it should be not less than 14010.82 million UAH in 2030. The predicted value of the ESG indicator $S$-component, namely the level of payments per full-time employee of transport, will reach over 0.28 million UAH per year by the economic and mathematical model (18) according to the determined earlier amounts of the capital investment and GDP. The predicted value of the ESG indicator $G$-component, namely the ratio of the number of employees who have undergone training, retraining and advanced training to the average number of full-time transport employees, will reach $40 \%$ in $2030(22.5 \%$ more than in 2019$)$ according to the economic and mathematical model (19).

Thus, the calculations show that the reduction of the carbon footprint of multimodal transportation by 2030 is possible under the condition of ESG investment in the industry, with a volume of at least 14010.82 million UAH. Therefore, the problem of creating the conducive regulatory framework for ESG investment should be recognized as the key issues of the multimodal transportation development, and, consequently, the effective and of full value use of the multimodal potential in Ukraine.

Undoubtedly, the government of Ukraine has been trying for several years to create a regulatory framework for ESG investing (Verkhovna Rada of Ukraine, 2017; Verkhovna Rada of Ukraine, 2018; Verkhovna Rada of Ukraine, 2019a; Verkhovna Rada of Ukraine, 2019b; Verkhovna Rada of Ukraine, 2020b; Verkhovna Rada of Ukraine, 2020c; Verkhovna Rada of Ukraine, 2020d; Verkhovna Rada of Ukraine, 2020e; Verkhovna Rada of Ukraine, 2020f). Since currently the Draft Law "On Multimodal Transportation" dated October 23, 2020 No. 4258 (Verkhovna Rada of Ukraine, 2020a) is still under consideration by the Verkhovna Rada of Ukraine, it is worth starting with the establishment of the Law of Ukraine (LU) "On Multimodal Transportation", as well as draft laws to stimulate and protect the interests and property of investors.

The next step in the formation of the regulatory framework for ESG investment should be the accession of the National Bank of Ukraine (hereinafter - NBU) to Net Zero Banking Alliance (NZBA), created at the initiative of the UN Environment Program.

Based on the obligations imposed on the NZBA members, the NBU must:

- determine goals and objectives for decarbonization of credit and investment resources for the next 20-30 years, within 18 months after joining the alliance;

- create a comprehensive database on reducing the carbon footprint in the framework of NVB2;

- introduce an ESG reporting verification system to prevent green washing (that is, creating a false ESG image of companies).

At the same time, the NBU should: establish European ecological and social standards in domestic practice; implement international standards for the disclosure of ESG information in the reporting of companies, since both institutional and private investors in ESG investments are primarily interested in information on business compliance with environmental and social responsibility, as well as corporate governance ethics; develop national recommendations for the formation of ESG-reporting based on the recommendations of the Global Task Force on ClimateRelated Financial Disclosure (TCFD), since the correct investment decision requires complete and reliable information about the activities of companies; the current financial reporting standards provide only financial information within the traditional paradigm of finance, while most of the non-financial information remains closed. Therefore, for corporate world, ESG-standards are new tendencies, which allow investors to take into account not only financial, but also non-financial factors and to determine the companies worth to be financed for a long period (Danilov et al., 2021); determine the recognition criteria and parameters of "light green", "dark green" and "brown" investments.

With the implementation of international standards for the disclosure of ESG-information in the reporting of enterprises to the Ministry of Finance of Ukraine in close cooperation with the Ministry of Environment and Natural Resources of Ukraine and the Ministry of Digital Transformation of Ukraine, national ESG-indices and technical components of the ESG Reporting Collection Center should be determined. In addition, its functional components should be determined. The components were designed to collect ESG-reporting in a single electronic format, based on the UA XBRL Taxonomy of IFRS 2020, approved on 09.04.2021 by the Financial Reporting System Management Committee (established under the Memorandum of Understanding on the development and implementation financial reporting system dated 18.12.2017 №102 / 15 (Ministry of Finance of Ukraine, 2017)).

Together with the ESG-Reporting Collection Center creation, a software service ESG-Report is advisable to develop technically ready for operation. It will provide stakeholders with access to information necessary for management decisions on ESG-investing, public dialogue and regulatory implementation (Liezina et al., 2020).

It is unacceptable to ignore ESG ratings. In order to ensure the most realistic rating of companies, it is advisable to form national ESG-rating standards, as well as to determine the rating and index agencies, market data providers, etc.

Administrative and criminal liability of business entities for environmental crimes and environmental offenses should be provided with the introduction of European ecological and social standards in the country. In addition, at the legislative level, it is necessary to clearly define the criteria for the recognition and differentiation of environmental crimes and environmental offenses.

It is advisable to provide for administrative and criminal liability of rating and scoring agencies, as well as providers of market data for "green washing".

Each of the listed stages of the formation of the regulatory framework for ESG investment is extremely important; therefore, we consider it unacceptable to ignore even one of them.

Summing up the above mentioned, we conclude that the Roadmap for the formation of an ESG investment regulatory framework should take the following form in Figure 6. 


\begin{tabular}{|c|c|}
\hline \multicolumn{2}{|c|}{ Roadmap for the creation of regulatory framework for ESG-investment } \\
\hline \multirow{4}{*}{$\begin{array}{c}\text { Formation of } \\
\text { the legal field } \\
\text { for ESG-investing }\end{array}$} & $\begin{array}{l}\text { Implementation of EU Council Directives in transport (Verkhovna Rada of Ukraine } \\
\text { (1992) }\end{array}$ \\
\hline & Enactment of LU "On Multimodal Transportation" \\
\hline & $\begin{array}{l}\text { Amendments and additions to the legislation on stimulating and protecting the interests } \\
\text { and property of investors }\end{array}$ \\
\hline & Establishment of "climate" law for financial institutions \\
\hline \multirow{5}{*}{$\begin{array}{l}\text { Formation of } \\
\text { the organizing field for } \\
\text { ESG-investing }\end{array}$} & Creation of the Green Transition Fund \\
\hline & Banks join the NZBA created on the financial initiative of the UN Environment Program \\
\hline & $\begin{array}{l}\text { For decarbonization of credit and investment resources defining goals and objectives for } \\
\text { the next } 20-30 \text { years }\end{array}$ \\
\hline & $\begin{array}{l}\text { Creation of a comprehensive database on carbon footprint reduction within } \mathrm{HBV} 2 \text { with } \\
\text { the participation of financial institutions }\end{array}$ \\
\hline & Development \& launch of a verification system of financial institutions ESG-reporting \\
\hline \multirow{4}{*}{$\begin{array}{l}\text { Standardization and } \\
\text { development of } \\
\text { recommendations }\end{array}$} & $\begin{array}{l}\text { Development of rating metrics for sustainability projects and climate change adaptation } \\
\text { projects when deciding on ESG investment }\end{array}$ \\
\hline & $\begin{array}{l}\text { Development of a methodology for determining the direct and related climate benefits of } \\
\text { ESG-investing }\end{array}$ \\
\hline & ESG-reporting standardization for financial institutions and companies \\
\hline & Standardization of rating of financial institutions and companies by ESG_performance \\
\hline \multirow{4}{*}{$\begin{array}{l}\begin{array}{c}\text { Digitization } \\
\text { of }\end{array} \\
\text { ESG-investing }\end{array}$} & Establishment of the ESG Reporting Center for Companies \\
\hline & Development of ESG-Report software service \\
\hline & Definition of ESG-rating and ESG-scoring agencies \\
\hline & Development \& launch of a verification system of ESG-reporting of companies \\
\hline \multirow{2}{*}{ Control \& responsibility } & Establishment of state ecological control \\
\hline & $\begin{array}{l}\text { Establishment of administrative and criminal liability for financial institutions and } \\
\text { business entities for "greenwashing" }\end{array}$ \\
\hline
\end{tabular}

Figure 6. Roadmap for the creation of the regulatory framework for ESG-investing in the multimodal transport development.

\section{Conclusion}

Thus, according to the results of the study, it was stated that the strategic guideline for the effective competitive national transport system development and the use of the multimodal potential of Ukraine was the formation of the regulatory framework for scaling ESG investment in the context of transformation to a "climate neutral" economy. The need for a high-quality implementation of it into life was noted. As there had been more than once the leveling of good intentions by their poor-quality implementation and thus receiving negative instead of the expected positive effect had happened in Ukraine.

The Roadmap for the creating the regulatory framework of ESG-investment with an arsenal of effective measures for its high-quality implementation in the Ukrainian practice of responsible investment was proposed. This should ensure high-quality implementation of ESG-investment in the multimodal transportation development that will provide positive changes in Ukraine's position in the world ranking of countries by the effectiveness of the multimodal potential use.

\section{References}

Abuselidze, G. (2021). Competitiveness Analysis of the Georgian Transport and Logistics System in the Black Sea Region: Challenges and Perspectives. Lecture Notes in Computer Science. 12952, 133-148. Springer, Cham. doi:10.1007/978-3-030-86973-1 10

Amel-Zadeh, A., Serafeim, G. (2018). Why and How 
Investors Use ESG Information: Evidence from a Global Survey. Financial Analysts Journal. 74(3), 87-103. doi:10.2469/faj.v74.n3.2.

Belashov, E. V. (2021). On the implementation of the potential of the transport system of Ukraine in the world container transportation market, National Institute for Strategic Studies, Retrieved August 10, 2021, from https://niss.gov.ua/sites/default/files/202103/transportna-systema.pdf

Chris, A., Edkins, M., Mitchem, K., Eliopoulos, T., Guillot J. (2017). The Next Wave of ESG Integration: Lessons from Institutional Investors. Journal of Applied Corporate Finance. 29(2), 32-43. doi:10.1111/jacf.12231.

Berezyuk, K. M. (2017). The evolution of the concept of corporate social responsibility in the context of changing business priorities. Economic Management: Theory and Practice. 9, 166-176.

Bowen, H. R. (2013). Social Responsibilities of the Businessman. doi:10.2307/j.ctt20q1w8f.

Council Directive 92/106 / EC "on establishing general rules for certain types of transportation of goods between member states" dated Retrieved August 10, 2021, from https://minjust.gov.ua/m/str_45893

Danilov, Y., Pivovarov, D., Davydov, I. (2021). Sustainable Finance Ratings. Russian Economic Developments. 4, 25-33.

Data \& Statistics - IEA, Retrieved August 10, 2021, from https://www.iea.org/data-and-

statistics? country $=\mathrm{UKRAINE} \&$ fuel $=\mathrm{CO} 2 \% 20 \mathrm{emissions} \& \mathrm{i}$ ndicator $=\mathrm{CO} 2 \mathrm{BySector}$

Eccles, R. G., Kastrapeli, M.D., Potter, S.J. (2017). How to Integrate ESG into Investment Decision-Making: Results of a Global Survey of Institutional Investors. Journal of Applied Corporate Finance. 29(4), 125-133. doi:10.1111/jacf.12267.

Garlytska, D., Sushchenko, O. (2017). From Corporate Social Responsibility to the ESG-Principles of Doing Business - A Way to Climate Finance. Ukrainian Securities Market. 5-6, 61-68.

Global Sustainable Investment Review (2018). Retrieved August 10, 2021, from http://www.gsi-alliance.org/wpcontent/uploads/2019/06/GSIR_Review2018F.pdf

Gorban, Y. S. (2016). Evolution of scientific approaches to human-environmental relations: public-managerial aspect. University research notes. 57, 262-272.

Greene W.H. (2018). Econometric Analysis, 8-th Edition, Stern School of Business, NY Univ., 2018.

Grim, D. M., Berkowitz, D. B. (2020). ESG, SRI, and Impact Investing: A Primer for Decision-Making. The Journal of Impact and ESG Investing. 1(1), 47-65.

doi:10.3905/jesg.2020.1.1.047.

Ji, Z., Abuselidze, G., Lymar, V. (2021). Problems and Perspectives of Sustainable Trade Development in China Under the One Belt One Road Initiative. E3S Web of Conferences. 258, 06050. doi:10.1051/e3sconf/202125806050.

Khasanov, A. (2015). Evolution of Corporate Governance: International experience. Society and Management. 2, 52-61.

Kim, S., Li, Z.F. (2021). Understanding the Impact of ESG Practices in Corporate Finance. Sustainability. 13(7), 3746. doi:10.3390/su13073746.
Kozak, L., Fedoruk, O. (2020). Features of the Formation of an Effective Model of Innovative Development of the Transport and Road Complex of Ukraine. Ekonomika ta derzhava. 3, 53-60. doi:10.32702/23066806.2020.3.53.

Kotsantonis, S., Pinney, Ch., Serafeim, G. (2016). ESG integration in investment management: Myths and realities. Journal of Applied Corporate Finance. 28(2), 10-16. doi:10.1111/jacf.12169.

Liezina, A. V., Andriushchenko, K. A., Rozhko, O. D., Datsii, O. I., Mishchenko, L. O., Cherniaieva, O. O. (2020). Resource Planning for Risk Diversification in the Formation of a Digital Twin Enterprise. Accounting. 6, 1337-1344. doi:10.5267/j.ac.2020.8.016.

Ministry of energy and environment protection of Ukraine (2019). Presentation of scenarios, policies and investments for Ukraine's second nationally defined contribution to the Paris Agreement.

Ministry of energy and environment protection of Ukraine (2019). National cadastre of anthropogenic emissions from sources and removals by sinks of greenhouse gases in Ukraine for 1990-2019.

Ministry of Finance of Ukraine (2017). Memorandum of understanding on the development and implementation of the Financial Reporting System №102/15, Retrieved August 10, 2021, from

https://zakon.rada.gov.ua/laws/show/v010220117\#Text

National accounts of Ukraine (2020). 2010-2019 statistical collection, State Statistics Service of Ukraine, Statistical Publication.

Pedro, M. (2020). ESG and responsible institutional investing around the world, Literature review, CFA Institute Research Foundation.

Petrenko I. S. (2016). Capital investments in Ukraine 20102015, Statistical collection, State Statistics Service of Ukraine, Statistical Publication.

Petrenko I. S. (2018). Capital investments in Ukraine 20162017, Statistical collection, State Statistics Service of Ukraine, Statistical Publication.

Porter, M. E., Kramer, M.R. (2011). Creating Shared Value: How to Reinvent Capitalism - and Unleash a Wave of Innovation and Growth, Harvard Business Review, pp. 63-70.

Savchenko, A.V. (2012). Directed Enumeration Method in Image Recognition. Pattern Recognition. 45(8), 2952-2961. doi:10.1016/j.patcog.2012.02.011.

Senyk, I. (2016). Working conditions of employees in 2015, Statistical collection, State Statistics Service of Ukraine, Statistical Publication.

Senyk, I. (2018). Working conditions of employees in 2017, Statistical collection, State Statistics Service of Ukraine, Statistical Publication, Retrieved August 10, 2021, from http://www.ukrstat.gov.ua/druk/publicat/kat_u/2018/z b/07/zb_pu2017_pdf.pdf

Senyk, I. (2018). Remuneration and social Labor Relations 2015-2017, Statistical collection, State Statistics Service of Ukraine, Statistical Publication.

Senyk, I. (2020). Labor of Ukraine in 2010-2019, Statistical collection, State Statistics Service of Ukraine, Statistical Publication, Retrieved August 10, 2021, from http://www.ukrstat.gov.ua/ 
Senyk, I. (2020). Employees' working conditions in 2019. State Statistics Service of Ukraine, Statistical Publication, Retrieved August 10, 2021, from

http://www.ukrstat.gov.ua/druk/publicat/kat_u/2020/zb/05/z b_upp_2019.pdf

Shyshkanova, G. (2018). About Stability of First Kind Equation Solving, 2018 IEEE First International Conference on System Analysis \& Intelligent Computing (SAIC) (October 2018). doi:10.1109/saic.2018.8516805.

Support to the government of Ukraine on updating its nationally determined contribution (NDC)

C40502/8492/47661, Retrieved August 10, 2021, from https://mepr.gov.ua/files/images/news_2020/2212202 0/Результати\%20моделювання.pdf

Tapio, P. (2005). Towards a Theory of Decoupling: Degrees of Decoupling in the EU and the Case of Road Traffic in Finland Between 1970 and 2001. Transport Policy. 12(2), 137-151. doi:10.1016/j.tranpol.2005.01.001.

Tian, Zh., Qiao,H., Tian, J., Zhu, H. Li, X. (2018). An Automated Brute Force Method Based on Webpage Static Analysis, 2018 10th International Conference on Measuring Technology and Mechatronics Automation (ICMTMA) (February 2018). doi:10.1109/icmtma.2018.00031.

UA XBRL taxonomy IFRS 2020 decision of the Financial Reporting System Management Committee. Retrieved August 10, 2021, from https://frs.gov.ua/

Van Duuren, E., Plantinga, A., Scholtens, B. (2016). ESG integration and the investment management process: Fundamental investing reinvented. Journal of Business Ethics. 138(3), 525-533. doi:10.1007/s10551-0152610-8.

Verkhovna Rada of Ukraine (1992). Council Directive 92/106 / EC "on the establishment of general rules for certain types of transportation of goods between member states"

Verkhovna Rada of Ukraine (2016). Paris climate agreement. Ratified by the law of Ukraine "on ratification of the Paris Agreement, Legislation of Ukraine, 1469, Retrieved August 10, 2021, from https://zakon.rada.gov.ua/laws/show/995_161\#n2.

Verkhovna Rada of Ukraine (2017). About investment activities, Law of Ukraine №1981-VIII, Retrieved August 10, 2021, from

https://zakon.rada.gov.ua/laws/show/1560-12\#Text

Verkhovna Rada of Ukraine, (2018). About the National
Transport Strategy of Ukraine for the period up to 2030, Legislation of Ukraine 430, Retrieved August 10, 2021, from https://zakon.rada.gov.ua/laws/show/430-2018$\%$ D1\%80?lang=en\#Text

Verkhovna Rada of Ukraine (2019a). On the basics of monitoring, reporting and verification of greenhouse gas emissions, Law of Ukraine №377-IX, August 10, 2021, Retrieved August 10, 2021, from https://zakon.rada.gov.ua/laws/show/377-20\#Text

Verkhovna Rada of Ukraine (2019b). About the concession, Law of Ukraine №155-IX, Retrieved August 10, 2021, from https://zakon.rada.gov.ua/laws/show/15520\#Text

Verkhovna Rada of Ukraine (2020a). About multimodal transportation, Draft Law Of Ukraine №4258, Retrieved August 10, 2021, from

https://w1.c1.rada.gov.ua/pls/zweb2/webproc4_1?pf3511=7 0239

Verkhovna Rada of Ukraine (2020b). On approval of the procedure for monitoring and reporting greenhouse gas emissions, Law of Ukraine №960-2020-ח, Retrieved August 10,2021, from

https://zakon.rada.gov.ua/laws/show/960-2020$\%$ D0\%BF\#Text

Verkhovna Rada of Ukraine (2020c). About state environmental control, Law of Ukraine №3091, Retrieved August 10, 2021, from

http://w1.c1.rada.gov.ua/pls/zweb2/webproc4_1?pf3511=6 8186

Verkhovna Rada of Ukraine (2020d). On state support for investment projects with significant investments in Ukraine, Law of Ukraine №1116-IX, August 10, 2021, from https://zakon.rada.gov.ua/laws/show/111620\#Text

Verkhovna Rada of Ukraine (2020e). On the basics of supporting new investments in Ukraine, Law of Ukraine №3201, Retrieved August 10, 2021, from

https://www.kmu.gov.ua/bills/proekt-zakonu-pro-zasadiderzhavnoi-pidtrimki-novikh-investitsiy-v-ukrainu

Verkhovna Rada of Ukraine (2020f). About the establishment of a business ombudsman in Ukraine, Law of Ukraine №3607, Retrieved August 10, 2021, from http://w1.c1.rada.gov.ua/pls/zweb2/webproc4_1?pf35 $11=69055$

Werner, I. (2020). There Is A Statistical Yearbook of Ukraine 2010-2019, Complex Statistical Publications, State Statistics Service of Ukraine, Statistical Publication. 